\title{
The Concept of Ideal Drug \&its Realization Opportunity using Nanopharmaceutical Research Scenario
}

\author{
Architha Aithal $^{1}$ \& P. S. Aithal ${ }^{2}$ \\ ${ }^{1}$ Srinivas College of Pharmacy, Valachil, Mangalore - 574143, INDIA \\ ${ }^{2}$ Srinivas Institute of Management Studies, Srinivas University, Mangalore - 575 001, INDIA \\ E-mail: aithalarchitha@gmail.com
}

Type of the Paper: Research Paper.

Type of Review: Peer Reviewed.

Indexed In: OpenAIRE.

DOI: http://doi.org/10.5281/zenodo.1469963.

Google Scholar Citation: IJHSP

\section{How to Cite this Paper:}

Aithal, Architha \& Aithal, P. S. (2018). The Concept of Ideal Drug \& its Realization Opportunity using Nanopharmaceutical Research Scenario. International Journal of Health Sciences and Pharmacy (IJHSP), 2(2), 11-26.

DOI: http://doi.org/10.5281/zenodo.1469963.

International Journal of Health Sciences and Pharmacy (IJHSP)

A Refereed International Journal of Srinivas University, India.

(C) With Authors

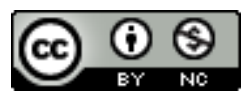

This work is licensed under a Creative Commons Attribution-Non Commercial 4.0 International License subject to proper citation to the publication source of the work.

Disclaimer: The scholarly papers as reviewed and published by the Srinivas Publications (S.P.), India are the views and opinions of their respective authors and are not the views or opinions of the SP. The SP disclaims of any harm or loss caused due to the published content to any party. 


\title{
The Concept of Ideal Drug \&its Realization Opportunity using Nanopharmaceutical Research Scenario
}

\author{
Architha Aithal $^{1}$ \& P. S. Aithal ${ }^{2}$ \\ ${ }^{1}$ Srinivas College of Pharmacy, Valachil, Mangalore - 574143, INDIA \\ ${ }^{2}$ Srinivas Institute of Management Studies, Srinivas University, Mangalore - 575 001, INDIA \\ E-mail: aithalarchitha@gmail.com
}

\begin{abstract}
New drug research is considered as a very important research area and probably found more investments of resources and time during the last few centuries. Drug research also contributed to the progress of medical sciences substantially and improving characteristics of drugs in terms of various predicted properties is continued as a challenge and agenda of these researches. Though the objective of drug research is continuous improvements of existing drugs in terms of their curing ability and to discover new drugs which have substantial improved abilities to cure many existing and new diseases, the final goal of drug research is directed to identifying one drug which has the ability to cure all diseases. Such drug system which can cure any diseases instantaneously is called ideal drug or ideal medicine. Based on the exact property expectations from a drug system as a medicine to cure all diseases is still unknown and a systematic study on the goal of ideal drug discovery is yet to be established. In this paper, we have made an attempt to identify the characteristics of an ideal drug which can cure all diseases in the universe. Further, we discussed the challenges and opportunities to realize such an ideal drug which can cure all the diseases. We also analysed the possibility of using nanotechnology which is emerging as universal technology to realize the possibility of developing ideal drug in practice. The advantages, benefits, constraints, and disadvantages of using nanotechnology in drug research with the goal of improving them towards an ideal drug system are also listed. Finally, the comparison is made between conventional drugs and nanotechnology based drugs in terms of Ideal System Characteristics.This paper is on futuristic research along with new knowledge creation and analysis based new interpretation of nanotechnology in medicinal drugs.
\end{abstract}

Keywords: Drug, Ideal Drug, Ideal Drug characteristics, Pharmaceutical Sciences, Nanotechnology, Nanomedicine.

\section{INTRODUCTION :}

A drug is a chemical material made up of various molecules obtained naturally or synthetically that affects the physiological functions of human beings/animals. Drug is used to diagnose, cure, treat, prevent, or relief some kind of discomfort in many types of diseases and the curing process is called drug therapy. The field pharmacology is focussed on the continual advancement of drugs and the field pharmacy is focussed on appropriate management of drugs.

Every drug interacts with the human body or any living systems (or vice-versa)through chemical processes and can be triggered through two major mechanisms which include activating or inhibiting normal body processes, and binding to regulatory molecules. The drug molecules usually different chemical reactions by disrupting some negative process occurring in the patient called Therapeutic Effects. It also causes Toxic effects, as used by parasites on their host. Thus, any drug can act like an agonist or an antagonist. An agonist drug acts as an activator or promotes the activity of a specific regulatory system or body process. An antagonist drug acts as an inhibitor, having the opposite effect to the agonist. The three general characteristics of an effective 
pharmacological drugare listed below [1-2] :

- The drug should have specific molecular size, shape, and charge to interact with the receptor.

- The drug molecule should able to travel to its site of action from its location of administration.

- The drug must be easily excreted from the body once it completes its action.

Apart from the above general physical properties of a drug, it should some additional desired characteristics like effectiveness in response, safety for the living body, and selectivity in action. If the drug is not effective in response, it should not be used. There is no such drugs a safe drug to the living body. All drugs will cause harm either directly or indirectly. There is no drug presently available in practice which is completely selective because all drugs can cause side effects. Thus effectiveness, safety, and selectivity of drug action are the challenges of drug research. Drug research is considered as a very important research area and probably found more investments of resources and time during the last few centuries [3]. Drug research also contributed to the progress of medical sciences substantially and improving characteristics of drugs in terms of various predicted properties is continued as a challenge and agenda of these researches. Focus on new drug discovery which has better properties towards achieving improvements in effectiveness, safety, and selectivity is the drug research agenda of many pharmaceutics research laboratories around the world. In order to further intensify the objectives of drug research, in this paper, we have predicted the characteristics expected in a hypothetical drug called ideal drug and also discussed the possibility of realizing such ideal drug in practice.

\section{IDEAL SYSTEMS RESEARCH :}

The word 'Ideal system' refers to the system which has ideal characteristics i.e., perfect in every way. The concept of ideal engine, ideal switch, ideal semiconductor devices like ideal diodes, transistors, etc. have been defined, studied and taken as standards to improve the quality and performance of such practical devices or systems. It is expected that, by keeping such a hypothetical device or systems in mind, researchers have continuously improved the characteristics/properties of practical devices/ systems to upgrade their performances. Hence ideal properties of a device or a system can be used to upgrade or improve its properties towards reaching 100\% efficiency. By comparing the properties/characteristics of a practical device/system with its ideal system counterpart, it is possible to modify the device /system towards reaching the objective of achieving such an ideal device [4]. It is clear that ideal systems are hypothetical systems, which cannot be realized completely in practice but they give a broad idea on how the practical systems can be improved continuously to reach ideal system characteristics. The ideal system characteristics of ideal technology [5], ideal business [6-7], ideal water purifier [8], ideal education [9-10], ideal banking [11-13], ideal electrical energy [14], ideal software [15], ideal computing [16],ideal library system [17] and ideal strategy [18], are discussed under input characteristics, system characteristics, output characteristics, and external characteristics shows an opportunity to the scientists and engineers to improve such practical systems further with an objective to reach the goal. Based on the review, we have also discussed the possible characteristics of some of the future anticipated systems like ideal automobiles, ideal home, ideal human being, ideal organization, ideal city, and even, ideal world [4].

\section{OBJECTIVES OF THE STUDY :}

This paper is conceptual in nature and uses predictive analysis methodology to build a model and analyse it. The objectives of the paper are as follows :

- To formulate a method to improve the performance of drugs by knowing the objectives of drug research.

- To study the characteristics of the ideal drug by considering it as an ideal system.

- To discuss the characteristics of the ideal drug in detail using ideal system model.

- To analyse the possibility of realising ideal drug in practice.

- To investigate the possibility of realising ideal drug using nanotechnology \&nanobiotechnology. 
- To compare the ideal drug characteristics with predicted nanotechnology-based drugs.

- To predict a timeline to achieve the expected solutions.

\section{IDEAL DRUG SYSTEM MODEL :}

The objective of drug research is continuous improvements of existing drugs in terms of their curing ability and to discover new drugs which have substantial improved abilities to cure many existing and new diseases and the final goal of drug research is directed to identifying one drug which has the ability to cure all diseases. All research work in pharmaceutics is directed towards improving drug properties including their effectiveness, safety, selectivity,no side effects, cost, accessibility, time of cure, etc. The ideal drug is a material which shows ideal characteristics. According to ideal drug model it is a system which operates on other systems based on its own properties and these properties are divided into input characteristics, operational characteristics, output characteristics, and environmental characteristics. Based on various factors which decides the ideal drug system characteristics, a model consisting of input conditions, output conditions, environmental conditions and system requirements are derived by a qualitative data collection instrument namely focus group method [19, 20]. The block diagram of such ideal drug system is shown in figure 1 . The expected characteristics of ideal drug under these categories are listed below:

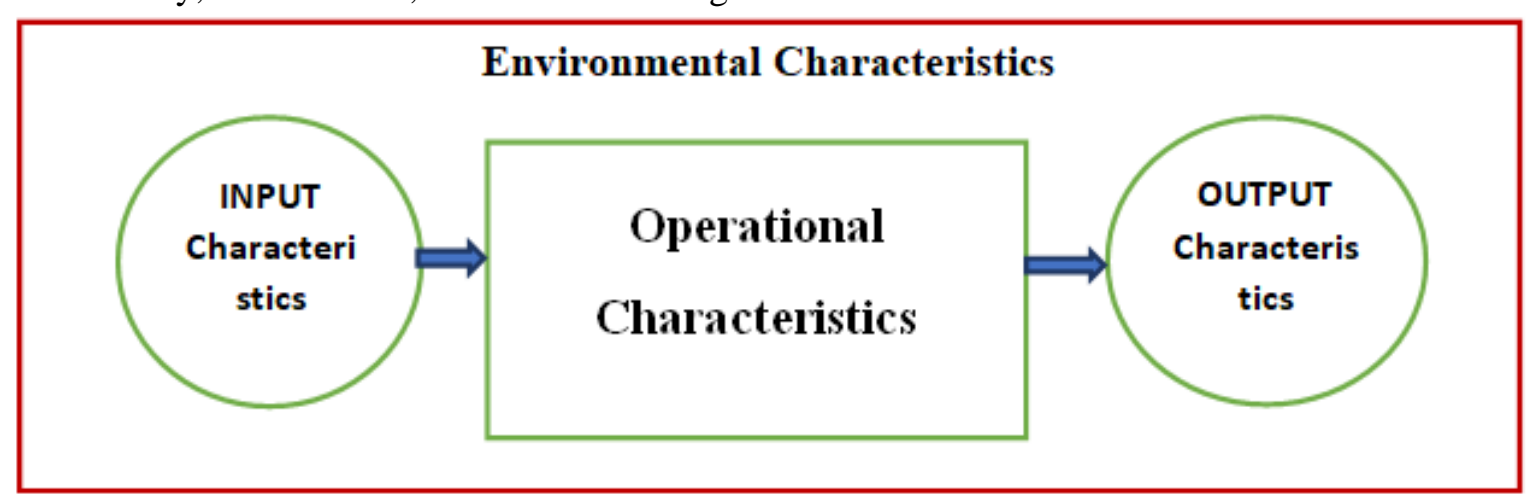

Fig. 1 : System model representation of Ideal drug in terms of its characteristics

(a) Input Characteristics :

(1) Ideal drug can have any type of physical state.

(2) Ideal drug independent on dosage.

(3) Ideal drug is a scalable system.

(4) Ideal drug is affordability for patients in terms of material usage.

(5) Ingredients used in ideal drug are abundant and freely available to everybody.

(b) System/Process Characteristics :

(1) Ideal drug should be non-toxic, biocompatible, and biodegradable.

(2) Ideal drug has no side effects.

(3) Ideal drug shows the selectivity in its action.

(4)Rate of ideal drug release is instantaneous and controllable.

(5) In ideal drug, the drug release has no relationship with the drug action.

(6) Ideal drug release is as per required therapeutic amount.
(7) No carrier is required to take ideal drug to reaction site.

(8) The delivery system for ideal drug should be easy, simple, and cost effective.

(9) The ideal drug should be easily eliminated from the body by simple metabolic processes after its action.

(10) The ideal drug will not get accumulated in any part of the body causing inflammation.

(11) Ideal drug is $100 \%$ effective in curing the disease.

(12) Ideal drug is100 \% safe for the living body.

(13) Ideal drug shows broad spectrum of efficacy.

(c) Output Characteristics :

(1) Ideal drug cures the disease completely.

(2) Ideal dug cures diseases immediately.

(3) Ideal drug produces no by-products.

(4) No repetition of same disease again.

(5) No therapies and rest required after 
recovery.

(d) Environmental Characteristics :

(1) No side effects so that it should be safe for users, and environment.

(2) No environmental harm and degradation.

(3) Location independence.

(4) Solutions to all types of health problems. Ideal drug cures every disease of every living human beings \& animals and hence decreases mortality. The ideal drug also helps to regenerate human organs where ever necessary. Hence it is expected that this hypothetical drug solves all health problems in the society.

\section{DESCRIPTIONS OF IDEAL DRUG MODEL :}

New drugs are designed and discovered by many scientists belonging to the subject called pharmaceutics. Pharmaceutics is the subject of pharmacy that deals with the process of discovering a new drug or old drugs into a new drug used by patients for curing their disease safely and effectively. The listed characteristics of ideal drug are further described below :

(a) Input Characteristics :

(1) Ideal drug can have any type of physical state :

The physical state of an ideal drug can be solid, liquid, or gases and the physical state of the drug is not a constraint for feeding it to the living body as medicine.

(2) Ideal drug independent on dosage :

The action and effect of the ideal drug are independent on the dosage. Whatever the quantity of drug is fed to the body will able to selectively cure the disease. In practice dosage increases with an increase in drug quantity and an optimum dosage is required to cure a particular disease of particular gravity.

(3) Scalable system :

Ideal drug is a scalable system and can be used for zero to infinite number of dosages to any number of patients. Practical drug systems have limited capacity in terms of dosage and scalability.

(4) Affordability in terms of material usage for Ideal Drug :

The materials used for the preparation of an ideal drug should be freely available in nature. The cost of an ideal drug should be zero so that everybody can afford for it.
(5) Ingredients used are abundant and freely available to everybody :

The ingredients used for the preparation of ideal drug are freely and abundantly available in all parts of the universe so that every living being has equal access to such ingredients to prepare the drug irrespective of their physical location.

(b) System/Process Characteristics :

(1) Ideal drug should be non-toxic, biocompatible, and biodegradable :

It is believed that all practical drugs are toxic for one or other organs of the living body. Drug reactions are of two types as allergic and toxic. Allergic drug reactions are independent on the dose of medication and are unpredictable. Toxic reactions occur in the body when there is an accumulated of too much drug in the bloodstream which leads to adverse effects on the body. Ideal drug by its definition does not be toxic to the body due to its nature of biocompatible and biodegradable. Biodegradation refers to the process by which the drug delivery system is broken down inside the body.

(2) Ideal drug has no side effects :

All practical drugs come with side effects. Some side effects are just an inconvenience, some are minor, a few are serious, and a few are just plain strange. Many drugs produce an allergic reaction which can range from itching and rash to even a life-threatening anaphylactic reaction. But as per the definition, the hypothetical ideal drug is free from all kinds of side effects.

(3) Ideal drug shows the selectivity in its action :

Restrict drug distribution to target cells or tissues or organs only and should have uniform capillary distribution. The ideal drug is highly specific in activity in identifying and curing the diseases. It also works with only diseased cells or organs and acts on it to cure the disease completely.

(4) Rate of ideal drug release is instantaneous and controllable :

Drug release is an important property of a therapeutic system, constituting a prerequisite to absorption of the therapeutic agent and one that contributes to the rate and extent of active availability to the body. When placed in a release medium, the agent that has to diffuse to the surface of the membrane for 
release immediately. In the case of an ideal drug, it is assumed that drug release is instantaneous and controllable, biodegradation occurs immediately through diffusion or dissolution.

(5) In ideal drug, the drug release has no relationship with the drug action :

In pharmacology, the drug action refers to the biochemical interaction with the specific molecular targets to which the drug binds, such as an enzyme or receptor. Drug release is an important property of a therapeutic system, constituting a prerequisite to absorption of the therapeutic agent and one that contributes to the rate and extent of active availability to the body. In case of an ideal drug, the drug release is instantaneous and has no relationship with the drug action.

(6) Ideal drug release is as per required therapeutic amount :

Since drug release is an important property of a therapeutic system in curing the diseases, it should be instantaneous and as per the requirement of the therapeutic amount in the releasing region. In case of practical drug release, there is no perfect equilibrium between optimum drug requirement in curing region and the drug release. But as per definition, in case of an ideal drug, the drug release amount is as per therapeutic requirement.

(7) No carrier is required to take an ideal drug to reaction site :

Ideal drug identifies its destination itself, i.e., its reaction site automatically and hence no carrier is required. Drug carrier is a material used along with the drug and is works to manage the drug release in a systematic circulation so that the selectivity, safety, and effectiveness of the drug can be improved. In case of an ideal drug, the drug itself identifies its destination so that no separate carrier is required.

(8) The delivery system for the ideal drug should be easy, simple, and cost effective :

Drug delivery is the method of administering a drug to achieve a therapeutic effect in a systematic manner. In practical drug delivery systems many concepts, methods, and techniques are used and together have been named as controlled release technology. Examples of controlled release technologies are transdermal and transmucosal controlled- release delivery systems, drug-impregnated lozenges, ml6 nasal and buccal aerosol sprays, encapsulated cells, iontophoretic devices to administer drugs through the skin, oral soft gels, and a variety of programmable, implanted drug-delivery devices [21]. These technologies are technically complex and expensive for the common man. As per the definition of the ideal drug, the delivery system for the ideal drug should be easy, simple, and cost effective.

(9) An ideal drug should be easily eliminated from the body by simple metabolic processes after its action :

Once the drug reaction is complete, the excess drug should be eliminated by a simple metabolic process so that there will be no side effects on any other cells or organs of the body. This is possible only in hypothetical ideal drug whereas, in conventional drugs, the side effect is due to the action of the drug with other regions/body parts which is unacceptable.

(10) The ideal drug will not get accumulated in any part of the body causing inflammation :

Inflammation is a self defence mechanism of the human body to heal any damaged cells, irritants, and pathogens. It is a part of every body's immune response. Usually, during medication, the part of the drug leftover or access in the body may cause inflammation which is unnecessary. But in the case of an ideal drug, since there is no accumulation of drug in any part of the body, there is no possibility of causing inflammation.

(11) Ideal drug is $100 \%$ effective in curing the disease :

All drugs are not equally effective in curing diseases. But as per the definition, an ideal drug cures a disease completely and is $100 \%$ effective.

(12) Ideal drug is100 \% safe for the living body :

Since the ideal drug is not showing any side effect due to its peculiar property of selectivity and noninflammability, it is completely safe to the living body.

(13) Ideal drug shows a broad spectrum of efficacy :

Efficacy means the ability to produce a desired or intended result. Broad spectrum of efficacy means the ideal drug can fight against both Gram-positive and Gram-negative bacteria or 
virus to cure the diseases.

(c) Output Characteristics :

(1) Ideal drug cures the disease completely :

An ideal drug defined here has the property to cure a given disease completely. An ideal disease can cure one or more disease completely. As per the definition, an ideal drug should cure all the diseases completely in every living being.

(2) Ideal dug cures diseases immediately:

The ideal drug defined here has property to cure a given disease instantaneously and completely. In case of the practical drugs, some of them may cure the diseases by killing or halting the spread of bacteria or viruses, some drugs may identify and kill cancerous cells in the body and some other drugs may replace missing substances or hormones or vitamins.

(3) Ideal drug produces no by-products :

Ideal drug is a hypothetical entity which does not produce any harmful by-products during the curing process. But the conventional drugs may produce adverse drug reactions in some living bodies due to the interaction of drug and its by-products with body cells.

(4) No repetition of the same disease again :

As per our assumption, when the ideal drug is inhaled, it has the ability to cure the diseases instantaneously and the drug cures the disease in such a way that it will never appear again in that living being, i. e., no repetition of the same disease again.

(5) No therapies and rest required after recovery:

Usually in practical drugs based curing, once the disease is cured the therapy should continue for some time for complete curing and during such time the patient is advised to take rest by the doctors. On the other hand, in the case of ideal drugs, no rest to the patient is required due to the fact that the disease completely cures instantaneously.

(d) Environmental Characteristics :

(1) No side effects so that it should be safe for users, and environment :

The ideal drug acts only on diseased cells and does not produce any harmful chemical during its action so that it has no side effect and hence is assumed to be safe to the users and environment.

(2) No environmental degradation :

Since the ideal drug is not producing any harmful chemical as the by-product, there is no excretion of harmful chemicals occurs from the body to the environment. As a result, the environment is not affected by the excreted drug discharge.

(3) Location independency :

Ideal drug yields same result of complete curing of diseases in any location around the world and in any time after the disease is started. The geographical factors and physical factors like temperature and pressure will not affect the expected performance of the ideal drug.

(4) Solutions to all health problems :

As per the definition of the ideal drug, it is always effective and gives quick solutions to any kind of diseases from a headache to cancer and hence solves all the health problems of living beings.

\section{CHALLENGES \&OPPORTUNITIES IN ACHIEVING IDEAL DRUG SYSTEM :}

As mentioned earlier, the concept of the ideal drug is purely hypothetical and looks strange but it gives appropriate direction for future research. This model gives the idea of the required quality improvement of various properties of the drug in order to cure the diseases and the opportunities and challenges in future research. The ideal drug model sets the goal of every researcher to decide their objectives while choosing the research topic related to drug discovery.

\section{(1) Opportunities :}

Ideal drug concept and characteristics based on the system model provides the following opportunities to drug researchers and drug manufacturers :

- Improve the quality of the drug by setting new objectives.

- Setting the target for the researchers to improve input, process, output, and environmental characteristics of the drugs.

- Continuous improvement opportunity by planning and researching in an identified characteristic.

- Focused research on issues related to the effectiveness of the drug, safety to patients, selectivity in drug action, decreased side effects, low cost, wide accessibility, less time for the cure, etc.

- To think on the realization of an Ideal drug with input characteristics like having any 
type of physical state, independent on dosage, scalability, affordability in terms of material usage for patients, and abundant and freely available ingredients usage.

- To also think and use the system process characteristics mentioned above while planning the drug discovery process.

- Drug manufacturing companies get new opportunity to use this model to re-define their objectives and enhance their R \& D activity along with $\mathrm{R} \& \mathrm{D}$ budget.

- The consumers/patients also get the opportunity to have access to improved drugs to cure their diseases.

(2) Challenges :

Apart from opportunities, the ideal drug concept posses many challenges for drug researchers, drug manufacturers, patients, health industry and even for the entire society. The individual characteristics under different headings like input, process, output, and environmental sections of the ideal drug system are really posing challenges for conventional thinkers and for the entire health industry. Converting these challenges into an opportunity to realize ideal characteristics of the drug at least individually if not altogether is the new goal of the health science research. The following are some of the challenges for drug researchers and drug manufacturers :

- The researchers face new challenges in their attempt to realize the ideal drug characteristics.

- The challenge of developing a material to be used as an ingredient to realize ideal drug.

- Manufacturing the drug using such ingredients which can possess ideal drug characteristics.

- The challenge of convincing the drug manufacturing companies to invest in attempting to realize the ideal drugs.

- Challenge on handling heavy resistance to be observed from the health science \& pharmacy community as they see it as a threat for their profession.

\section{NANOTECHNOLOGY AS UNIVERSAL TECHNOLOGY :}

Nanotechnology is expected as a technology of the $21^{\text {st }}$ century to solve many problems of society both at primary and secondary level [22-23]. Nanotechnology allows many fields of science and technologies to converge to single integrated technology and offers a new way to solve problems of society both at fundamental and applied levels. Such convergence ability of nanotechnology from many fields to single field leadsan increase in interdisciplinary research at the nanoscale. Many nanotechnology interdisciplinary groups for interdisciplinary research are formed in this century all over the world during recent years to accelerate the research and development in nanotechnology and related areas. Nanotechnology has solutions of many problems of agriculture to get nutritious food to every living being of the world, potable water for drinking and irrigation, renewable energy for essential human activities, many new and essential consumer durable systems, and better healthcare facilities. Nanotechnology is expected to change the definition and principle of functioning of many products and services provided by various industries to their customers as general purpose technology [24]. It is expected that the effect of Nanotechnology (NT) along with another already matured technology called Information Communication and Computation Technology (ICCT) is enormous in future days in the society on lifestyle of human beings and these two technologies are expected to solve many problems and requirements of the society and hence named them as Universal Technologies [25]. Being one of the Universal technologies, nanotechnology has huge hope in solving all the problems of living beings related to health sciences. Many problems in medical sciences have already anticipated solutions at least at conceptual level using nanotechnology and ICCT. In the next section, we have discussed the anticipated breakthroughs of nanotechnology solutions in health and medical science problems and hence the possibility of realizing the ideal drug characteristics using nanobiotechnology in future years.

\section{POSSIBILITY OF REALIZING IDEAL DRUG USING NANOTECHNOLOGY :}

Nanotechnology being a general-purpose technology of $21^{\text {st }}$ century and growing as universal technology has solution in the process of developing ideal solutions to health and medical sciences problems. 
Nanotechnology is evolving as a new hope to create and utilization of materials and tools at nanometer scale and influencing number of industries in health and medical sciences including in particularly pharmaceutical industry. Nanotechnology tools and techniques developed for different industry sectors along with biotechnology ideas have potential opportunities in achieving ideal drug characteristics in pharmaceutical industry. It is also believed that nanotechnological tools suitable for improving the characteristics of drugs towards ideal drug are exotic, disruptive, and futuristic so that may take long time in terms of several hundred years for commercialization. Currently nanoparticles and nanodevices such as nanobiosensors and nanobiochips, are used to discover new drugs or to improve the characteristics of existing drug in pharmaceutical research industry. This include :

- Some nanosubstanceslike fullerenes are considered as potential drugs for the future healthcare industry.

- The nanoparticle based drug delivery systems allows to target drugs to specific areas of the body [26].

- The medical imaging technique is expected to utilize drug delivery systems to illuminate to any cellular functions including tumors, or the brain in the body [27].

- The nano scale drug particles can reach inaccessible areas in the body such as inflamed tissues due to their improved permeability and retention effect.

- New nano-scale drug carriers are developed using dendrimers, to increase the possibility of increasing therapeutic index of drug molecules [28].

- The nanotechnology based long acting injectable therapies for HIV treatment [29].

- The nanomaterial based systems are used as carriers of antibiotics for infectious diseases [30].

- Various nanoparticles, and nanofibers and nanoporous scaffoldsare used in the fabrication scaffolds for nanoengineering scaffolds to replaced and re-grow damaged tissues and organs [31].

- Silica based mesoporous nanomaterials with surface reactive functionalities are used for bone tissue engineering[32].

- Use of nanomedicine for managing diabetics [33].

Based on such many possibilities discovered till now, there is a hope that many more diseases may find optimal curing solutions in future days using nanotechnology based techniques.

\section{CURRENT RESEARCH AGENDAS IN NANOTECHNOLOGY BASED DRUG RESEARCH :}

Nanotechnology is a useful tool to improve the selective delivery of drug to the specific site of action. Recent developments in nanotechnology to engineer nanoparticles with desired physicochemical properties have been projected as a new line of defence against many diseases. Table 1 summarizes some of the current research agendas in nanotechnology based drug research.

Table 1: Some of the current research agendas in Nanotechnology based Drug research

\begin{tabular}{|l|l|l|l|}
\hline $\begin{array}{l}\text { S. } \\
\text { No. }\end{array}$ & Type of disease & Nanotechnology based solution & Reference \\
\hline 1 & Bone related disease & $\begin{array}{l}\text { Development of nanomaterials } \\
\text { for bone-targeted drug delivery }\end{array}$ & Cheng, H. et al. (2017) [34] \\
\hline 2 & $\begin{array}{l}\text { Tissue } \\
\text { regeneration, drug } \\
\text { delivery and } \\
\text { pharmaceuticals }\end{array}$ & $\begin{array}{l}\text { Electrosprayed nanoparticles and } \\
\text { electrospun nanofibers based on } \\
\text { natural materials }\end{array}$ & Sridhar, R., et al (2015) [35] \\
\hline 3 & Oncologic Disease & Nanomedicine & $\begin{array}{l}\text { Brown, P. D., et al. (2015) } \\
\text { [36] }\end{array}$ \\
\hline 4 & Cancer therapy & $\begin{array}{l}\text { Nanotechnology-based } \\
\text { chemotherapy }\end{array}$ & $\begin{array}{l}\text { Coccia, M. et al. (2015) [37] } \\
\text { Singh, D. et al (2017) [38] }\end{array}$ \\
\hline 5 & Neural regeneration & Nanotechnology-based approaches & Shah, S. et al (2015) [39] \\
\hline
\end{tabular}




\begin{tabular}{|c|c|c|c|}
\hline & & iding neural regeneration & \\
\hline 6 & $\begin{array}{l}\text { Liver tissue } \\
\text { engineering }\end{array}$ & $\begin{array}{l}\text { Primary liver cells cultured on } \\
\text { carbon nanotube substrates }\end{array}$ & $\begin{array}{l}\text { Che Abdullah et al (2014) } \\
\text { [40] }\end{array}$ \\
\hline 7 & $\begin{array}{l}\text { Treatment of } \\
\text { melanoma }\end{array}$ & $\begin{array}{ll}\text { Nanoparticle-mediated } & \text { drug } \\
\text { delivery }\end{array}$ & Mundra, V. et al (2015) [41] \\
\hline 8 & Drug delivery & Synthetic micro/nanomotors & Gao, W. et al (2014) [42] \\
\hline 9 & $\begin{array}{l}\text { Treatment and } \\
\text { eradication of } \\
\text { HIV/AIDS }\end{array}$ & $\begin{array}{l}\text { Nanodrug formulations to enhance } \\
\text { HIV drug exposure in lymphoid } \\
\text { tissues and cells }\end{array}$ & Shao, J. et al (2016) [43] \\
\hline 10 & $\begin{array}{l}\text { Delivery of peptide } \\
\text { nucleic acids (PNAs). }\end{array}$ & Nanotechnology based solutions & Gupta, A. et al (2016) [44] \\
\hline 11 & \begin{tabular}{|l}
$\begin{array}{l}\text { Controlled drug } \\
\text { release }\end{array}$ \\
\end{tabular} & Pharmaceutical nanocarriers & Lee, J. H. et al (2015) [45] \\
\hline 12 & $\begin{array}{l}\text { Smart drug delivery in } \\
\text { cancer therapy }\end{array}$ & $\begin{array}{l}\text { Ph-sensitive } \\
\text { nanoparticles }\end{array}$ & Lim, E. K., et al (2018) [46] \\
\hline 13 & $\begin{array}{l}\text { Alzheimer's disease } \\
\text { therapy }\end{array}$ & Nanotechnology approach & $\begin{array}{l}\text { Ansari, S. A. et al (2017) } \\
\text { [47] }\end{array}$ \\
\hline 14 & Parkinson's disease & $\begin{array}{l}\text { Nanotechnology-mediated nose to } \\
\text { brain drug delivery }\end{array}$ & $\begin{array}{l}\text { Kulkarni, A. D., et al (2015) } \\
\text { [48] }\end{array}$ \\
\hline 15 & Tube & $\begin{array}{l}\text { Nanotechnology-Based approach in } \\
\text { tuberculosis treatment }\end{array}$ & $\begin{array}{l}\text { Nasiruddin, M., et al (2017) } \\
\text { [49] }\end{array}$ \\
\hline 16 & Drug delivery platform & $\begin{array}{l}\text { Biofunctionalized nanoparticles- } \\
\text { baseddrug delivery platform }\end{array}$ & Bose, R. J. et al (2016) [50] \\
\hline 17 & $\begin{array}{l}\text { Preclinical imaging \& } \\
\text { drug delivery }\end{array}$ & DNA nanomaterials & Jiang, D. \\
\hline 18 & \begin{tabular}{|ll}
$\begin{array}{l}\text { Cancer } \\
\text { treatment }\end{array}$ & metastasis \\
\end{tabular} & $\begin{array}{ll}\text { Nanotechnology-based intelligent } \\
\text { drug design }\end{array}$ & $\begin{array}{l}\text { Gao, Y. e } \\
\text { [52] }\end{array}$ \\
\hline 19 & HIV AIDS treatment & Nanotechnology: a magic bullet & $\begin{array}{l}\text { Kumar, L. et al (2015) } \\
\text { [53] }\end{array}$ \\
\hline 20 & Antibacterial Agents & Silver Nanoparticles & $\begin{array}{l}\text { Franci, G. et al (2015) } \\
\text { [54] }\end{array}$ \\
\hline 21 & \begin{tabular}{|lr} 
New method & for \\
potent & drug \\
development & \\
\end{tabular} & Biological nanomotors & $\begin{array}{l}\text { Pi, F. et al (2016) } \\
\text { [55] }\end{array}$ \\
\hline 22 & $\begin{array}{l}\text { Broad-spectrum } \\
\text { treatment of viral } \\
\text { infections }\end{array}$ & $\begin{array}{l}\text { Nanomedicine for infectious } \\
\text { disease applications }\end{array}$ & Jackman, J. et al (2016) [56] \\
\hline 23 & $\begin{array}{l}\text { Eradicating } \\
\text { reservoirs }\end{array}$ & Nanotechnology approach & $\begin{array}{l}\text { Cao, S. et al (2018) } \\
{[57]}\end{array}$ \\
\hline 24 & \begin{tabular}{|l|} 
Ocular \\
diseases \\
\end{tabular} & $\begin{array}{l}\text { Role of nanotechnology in control } \\
\text { of human diseases }\end{array}$ & $\begin{array}{l}\text { Rai, M. et al (2016) } \\
\text { [58] }\end{array}$ \\
\hline 25 & \begin{tabular}{|l|} 
Coronary \\
disease
\end{tabular} & $\begin{array}{l}\text { Nanotechnology in diagnosis and } \\
\text { treatment }\end{array}$ & $\begin{array}{l}\text { Karimi, M. et al (2016) } \\
\text { [59] }\end{array}$ \\
\hline 26 & $\begin{array}{l}\text { Treatment } \\
\text { tuberculosis }\end{array}$ & $\begin{array}{l}\begin{array}{l}\text { Nanotechnology } \\
\text { platform }\end{array} \\
\end{array}$ & $\begin{array}{l}\text { Choudhary, S. et al (2015) } \\
\text { [60] }\end{array}$ \\
\hline 27 & $\begin{array}{l}\text { Brain cancer and } \\
\text { Alzheimer's disease }\end{array}$ & $\begin{array}{l}\text { Nano-enabled drug delivery } \\
\text { systems }\end{array}$ & $\begin{array}{l}\text { Ma, J. et al (2015) } \\
\text { [61] }\end{array}$ \\
\hline
\end{tabular}

10. ABCD LISTING OF NANOTECHNOLOGY IN DRUG DISCOVERY :

(1) Advantages :
- Nanotechnology has given rise to promising new therapies and diagnostic tools for a wide range of diseases, especially cancer. 
- The most important advantage offered by nanotechnology is the ability to specifically target organs, tissues, and individual cells.

- Nanotechnology-based drug delivery systems improve delivery of photosensitizers which are poorly watersoluble and facilitates them to reach intracellular sites of action.

- Nanotechnology systems can be designed and developed for the sustained release of drugs from the matrix and drug delivery to a specific target.

- Nanotechnology based drugs increase absorption, bioavailability, and controlled release of the drug at the site of administration.

- Provides faster, smaller, and highly sensitive diagnostic tools \& techniques.

(2) Benefits :

- Nanotechnology in oncology offers selectively killing the tumour cells without harming healthy cells.

- The ability of nanotechnology to specifically target organs, tissues, and individual cells, ultimately leads to decrease the systemic side effects and hence improves the therapeutic index of drug molecules.

- The sustainable drug release properties of the nanotechnology systems enable the improvement of the bioavailability of drugs, can reduce the dosage and frequency of administration, and may solve the problem of non-adherence to prescribed therapy.

- Increased effectiveness of the drug, safety to patients, and selectivity in drug action,

- Nanotechnology based drugs provide decreased side effects, low cost, wide accessibility, less time for the cure, etc.
- Help to solve many unsolved health problems.

(3) Constraints :

- The process of detection, quantification, and removal of toxin part from nanoformulations while using them as drugs or carriers of drugs.

- It is predicted that nanomaterials used as the drug may give damage to lungs or any other organs in the body.

- Large-scale manufacturing and costs of nanomedicines are also important issues to be addressed.

- The research on drugs based on nanotechnology is under planning and development stage so that awareness about the consequence is yet to be created.

(4) Disadvantages :

- The safety issues of nanomaterial based drugs are not clear and yet to be convinced to the society.

- The cost associated with nanotechnology based research is presently high so that the cost of nanomedicines are accordingly high.

- Superspeciality research in nanotechnology based drug development is rare due to less number of experts in the field.

11. COMPARISON OF CONVENTIONAL DRUG AND NANOTECHNOLOGY BASED DRUG IN TERMS OF IDEAL SYSTEM CHARACTERISTICS :

Table 2 compares the conventional drug and nanotechnology based drug in terms of ideal business characteristics. The table shows that the nanotechnology based drug characteristics can be improved close to ideal drug characteristics.

Table 2: Comparison of conventional drug and nanotechnology based drug

\begin{tabular}{|l|l|c|c|}
\hline S. No. & Ideal Drug Characteristics & Conventional Drug & NT based Drug \\
\hline 1 & Any type of physical state & Yes & Yes \\
\hline 2 & Independent on dosage & No & Yes \\
\hline 3 & Scalable system & No & Yes \\
\hline 4 & $\begin{array}{l}\text { Affordability for patients in terms of } \\
\text { material usage }\end{array}$ & $\begin{array}{l}\text { No } \\
\text { available used are abundant and freely }\end{array}$ \\
\hline 5 & $\begin{array}{l}\text { Non-toxic, biocompatible, and } \\
\text { biodegradable }\end{array}$ & No & Possible \\
\hline 6
\end{tabular}




\begin{tabular}{|c|c|c|c|}
\hline 7 & No side effects & No & Possible \\
\hline 8 & Selectivity in its action & No & Possible \\
\hline 9 & $\begin{array}{l}\text { Rate of release is instantaneous and } \\
\text { controllable }\end{array}$ & No & Possible \\
\hline 10 & $\begin{array}{l}\text { Drug release has no relationship with the } \\
\text { drug action }\end{array}$ & No & Possible \\
\hline 11 & $\begin{array}{l}\text { Drug release is as per required therapeutic } \\
\text { amount }\end{array}$ & No & Yes \\
\hline 12 & $\begin{array}{l}\text { No carrier is required to take drug to } \\
\text { reaction site }\end{array}$ & No & Yes \\
\hline 13 & $\begin{array}{l}\text { Delivery system should be easy, simple, } \\
\text { and cost effective }\end{array}$ & No & Possible \\
\hline 14 & $\begin{array}{l}\text { Drug should be easily eliminated from the } \\
\text { body by simple metabolic processes after } \\
\text { its action }\end{array}$ & No & Possible \\
\hline 15 & $\begin{array}{l}\text { Drug will not get accumulated in any part } \\
\text { of the body causing inflammation }\end{array}$ & No & Possible \\
\hline 16 & $100 \%$ effective in curing the disease & No & Possible \\
\hline 17 & $100 \%$ safe for the living body & No & Possible \\
\hline 18 & Shows broad spectrum of efficacy & No & Possible \\
\hline 19 & Cures the disease completely & Possible & Possible \\
\hline 20 & Cures diseases immediately & No & Possible \\
\hline 21 & Produces no by-products & No & Possible \\
\hline 22 & No repetition of same disease again & No & Possible \\
\hline 23 & $\begin{array}{l}\text { No therapies and rest required after } \\
\text { recovery }\end{array}$ & No & Possible \\
\hline 24 & No side effects & No & Possible \\
\hline 25 & No environmental harm and degradation & No & Possible \\
\hline 26 & Location independence & Possible & Yes \\
\hline 27 & Solutions to all types of health problems & No & Possible \\
\hline
\end{tabular}

\section{CONCLUSION :}

The ultimate objective of health science is precaution and prevention of all types of diseases of living animals including human beings. Both prevention and curing of diseases need suitable drug/medicine system. The drugs presently used for different diseases have many limitations and need to be improved in terms of their ability to cure the disease completely. In this paper, we have defined a so-called ideal drug system which can help the researchers and decision makers in the drug industry to redefine their objective in research and development in the pharmaceutical industry. The drug system which can cure any diseases instantaneously is called ideal drug or ideal medicine. Based on the exact expectations of the properties from a drug system as a medicine to cure all diseases, we tried to identify the characteristics of an ideal drug which can cure all diseases in the universe. Further, we also discussed the challenges and opportunities to realize such an ideal drug which can cure all the diseases.

Further, we also analysed the possibility of using nanotechnology which is emerging as universal technology to realize the possibility of developing ideal drug and in this context, on some of the research agendas focussed on solving various diseases using nanotechnology are analysed. The advantages, benefits, constraints, and disadvantages of using nanotechnology in drug research with the goal of improving them towards an ideal drug system are also listed. Finally, the comparison is made between conventional drugs and nanotechnology based drugs in terms of Ideal System Characteristics.This paper is on futuristic research along with new knowledge creation and analysis based new interpretation of nanotechnology in medicinal drugs.

\section{REFERENCES :}

[1] http://theartofmed.wordpress.com/2015 105/8/introduction-to-pharmacology-i- 
characteristics-of-drugs/. Retrieved on 10 /10/2018.

[2] http://hubpages.com/education/Characteris tics-of-Drug. Retrieved on 05/10/2018.

[3] Kubinyi, H. (2003). Drug research: myths, hype and reality. Nature Reviews Drug Discovery, 2(8), 665.

[4] Aithal, P. S. (2016). Review on Various Ideal System Models Used to Improve the Characteristics of Practical Systems. International Journal of Applied and Advanced Scientific Research, 1(1), 4756.DOI

:http://doi.org/10.5281/zenodo.159749.

[5] Aithal, P. S., \&Shubhrajyotsna Aithal, (2015). Ideal Technology Concept \& its Realization Opportunity using Nanotechnology, International Journal of Application or Innovation in Engineering \& Management (IJAIEM), 4(2), 153 164.

DOI: http://doi.org/10.5281/zenodo.61591.

[6] Aithal, P. S. (2015). Concept of Ideal Business \& Its Realization Using EBusiness Model. International Journal of Science and Research (IJSR), 4(3), 1267 - 1274. ISSN 2319-7064, DOI :http://doi.org/10.5281/zenodo.61648.

[7] Aithal, P. S. (2015). Mobile Business as an Optimum Model for Ideal Business. International Journal of Management, IT and Engineering (IJMIE), 5(7), 146-159, DOI

:http://doi.org/10.5281/zenodo.163880.

[8] Aithal, Shubrajyotsna\& Aithal, P. S. (2018). Concept of Ideal Water Purifier System to Produce Potable Water and its Realization Opportunities using Nanotechnology. International Journal of Applied Engineering and Management Letters (IJAEML), 2(2), 8-26. DOI: http://doi.org/10.5281/zenodo.1323714.

[9] Aithal P. S. and Shubhrajyotsna Aithal, (2014). Ideal education system and its realization through online education model using mobile devices. Proceedings of IISRO Multi Conference 2014, Bangkok, pp.140 - 146, ISBN No. 97881-927104-33-13.DOI:

http://doi.org/10.5281/zenodo.62059.
[10] Aithal P. S. and Shubhrajyotsna Aithal, (2015). An Innovative Education Model to realize Ideal Education System. International Journal of Scientific Research and Management (IJSRM), 3(3), $2464 \quad$ - 2469. DOI: http://doi.org/10.5281/zenodo.61654.

[11] Aithal, P. S. (2016). Ideal Banking Concept and Characteristics. International Research Journal of Management, IT and Social Sciences (IRJMIS), 3(11), 46-55. DOI :http://doi.org/10.21744/irjmis.v3i11.311.

[12] Aithal, P. S. (2016). Realization of Ideal Banking Concept using Ubiquitous Banking, International Journal of Scientific Research and Modern Education (IJSRME), 1(2), 119-135. DOI: http://doi.org/10.5281/zenodo.164703.

[13] Aithal, P. S. (2016). A Comparison of Ideal Banking Model with Mobile Banking System. International Journal of Current Research and Modern Education (IJCRME), 1(2), 206-224. DOI:http://doi.org/10.5281/zenodo.19870 8.

[14] Sridhar Acharya P. \& Aithal P. S., (2016). Concept of Ideal Electric Energy System for production, distribution and utilization. International Journal of Management, IT and Engineering (IJMIE), 6(1), 367-379. DOI :http://doi.org/10.5281/zenodo.161143.

[15] Aithal, P. S. \&Vaikuth Pai, T., (2016). Concept of Ideal Software and its Realization Scenarios. International Journal of Scientific Research and Modern Education (IJSRME), 1(1), 826837. DOI : $\quad$ http://doi.org/10.5281/ zenodo.160908.

[16] Aithal, P. S. \&Priyesh Pai, T. (2017). Opportunity for Realizing Ideal Computing System using Cloud Computing Model. International Journal of Case Studies in Business, IT and Education (IJCSBE), 1(2), 60-71. DOI: http://doi.org/10.5281/zenodo.1094995.

[17] Aithal P. S. (2016). Smart Library Model for Future Generations. International Journal of Engineering Research and 
Modern Education (IJERME), 1(1), 693703. DOI :http://doi.org/10.5281/zenodo.160904.

[18] Aithal P. S. (2016). The concept of Ideal Strategy \& its realization using White Ocean Mixed Strategy. International Journal of Management Sciences and Business Research (IJMSBR), 5(4), 171$179 . \quad$ DOI :http://doi.org/ 10.5281/zenodo.161108.

[19] Shubrajyotsna Aithal, \& Aithal, P. S., Bhat,G. K. (2016). Characteristics of Ideal Optical Limiter and Realization Scenarios using Nonlinear Organic Materials - A Review. International Journal of Advanced Trends in Engineering and Technology (IJATET), 1(1), 73-84. DOI :http://doi.org/10. 5281/zenodo.240254.

[20] Rogers E.M., (1995) Diffusion of Innovation, The Free Press, NY.

[21] Tiwari, G., Tiwari, R., Sriwastawa, B., Bhati, L., Pandey, S., Pandey, P., \&Bannerjee, S. K. (2012). Drug delivery systems: An updated review. International journal of pharmaceutical investigation, 2(1), 2.

[22] Aithal, P. S., Shubhrajyotsna Aithal, (2015). A review on Anticipated Breakthrough Technologies of 21st Century. International Journal of Research \& Development in Technology and Management Sciences, 21(6), 112 133. DOI : :http://doi.org/10.5281/zen do.61617.

[23] Aithal, P. S. (2016). Nanotechnology Innovations \& Business Opportunities : A Review. International Journal of Management, IT and Engineering (IJMIE), 6(1), 182-204. DOI :http://doi.org/10.5281/z enodo.161153.

[24] Aithal, P. S. and Shubhrajyotsna Aithal. (2018). Study of various General-Purpose Technologies and their contribution towards developing Sustainable Society, International Journal of Management, Technology, and Social Sciences (IJMTS), 3(2), 16-33. DOI : http://doi.org/10.5281/Zenodo.1409476.

[25] Aithal P. S. \&Shubhrajyotsna Aithal,
(2018). Nanotechnology based Innovations and Human Life Comfortability -Are we Marching towards Immortality ?. International Journal of Applied Engineering and Management Letters (IJAEML), 2(2), 71-86. DOI : https://doi.org/10.5281/zenodo.1451498.

[26] Lata, S., Sharma, G., Joshi, M., Kanwar, P., \& Mishra, T. (2017). Role of nanotechnology in drug delivery. Int $J$ NanotechnolNanosci, 5, 1-29.

[27] Kunjachan, S., Ehling, J., Storm, G., Kiessling, F., \& Lammers, T. (2015). Noninvasive imaging of nanomedicines and nanotheranostics: principles, progress, and prospects. Chemical reviews, 115(19), 10907-10937.

[28] Valavanidis, A., \&Vlachogianni, T. (2016). Engineered nanomaterials for pharmaceutical and biomedical products new trends, benefits and opportunities. Journal of Pharma Reports, 1(1), 1-8. DOI :http://doi. org/10.4172/jpr.1000105.

[29] Owen, A., \&Rannard, S. (2016). Strengths, weaknesses, opportunities and challenges for long acting injectable therapies: insights for applications in HIV therapy. Advanced drug delivery reviews, 103, 144-156.

[30] Qasim, M., Lim, D. J., Park, H., \& Na, D. (2014). Nanotechnology for diagnosis and treatment of infectious diseases. Journal of nanoscience and nanotechnology, 14(10), 7374-7387.

[31] Tasciotti, E., Cabrera, F. J., Evangelopoulos, M., Martinez, J. O., Thekkedath, U. R., Kloc, M., ... \& Ferrari, M. (2016). The emerging role of nanotechnology in cell and organ transplantation. Transplantation, 100(8), 1629.

[32] Walmsley, G. G., McArdle, A., Tevlin, R., Momeni, A., Atashroo, D., Hu, M. S., ... \& Wan, D. C. (2015). Nanotechnology in bone tissue engineering. Nanomedicine:

Nanotechnology, Biology and Medicine, 11(5), 1253-1263.

[33] Veiseh, O., Tang, B. C., Whitehead, K. 
A., Anderson, D. G., \& Langer, R. (2015). Managing diabetes with nanomedicine: challenges and opportunities. Nature Reviews Drug Discovery, 14(1), 45.

[34] Cheng, H., Chawla, A., Yang, Y., Li, Y., Zhang, J., Jang, H. L., \&Khademhosseini, A. (2017). Development of nanomaterials for bone-targeted drug delivery. Drug discovery today, 22(9), 1336-1350.

[35] Sridhar, R., Lakshminarayanan, R., Madhaiyan, K., Barathi, V. A., Lim, K. H. C., \& Ramakrishna, S. (2015). Electrosprayed nanoparticles and electrospun nanofibers based on natural materials: applications in tissue regeneration, drug delivery and pharmaceuticals. Chemical Society Reviews, 44(3), 790-814.

[36] Brown, P. D., \& Patel, P. R. (2015). Nanomedicine: a pharma perspective. Wiley Interdisciplinary Reviews: Nanomedicine and Nanobiotechnology, 7(2), 125-130.

[37] Coccia, M., \& Wang, L. (2015). Pathbreaking directions of nanotechnologybased chemotherapy and molecular cancer therapy. Technological Forecasting and Social Change, 94, 155169.

[38] Singh, D., Minz, A. P., \& Sahoo, S. K. (2017). Nanomedicine-mediated drug targeting of cancer stem cells. Drug discovery today, 22(6), 952-959.

[39] Shah, S., Solanki, A., \& Lee, K. B. (2015). Nanotechnology-based approaches for guiding neural regeneration. Accounts of chemical research, 49(1), 17-26.

[40] Che Abdullah, C. A., Lewis Azad, C., Ovalle-Robles, R., Fang, S., Lima, M. D., Lepró, X., ... \& Sear, R. P. (2014). Primary liver cells cultured on carbon nanotube substrates for liver tissue engineering and drug discovery applications. ACS applied materials \& interfaces, 6(13), 10373-10380.

[41] Mundra, V., Li, W., \&Mahato, R. I. (2015). Nanoparticle-mediated drug delivery for treating melanoma. Nanomedicine, 10(16), 26132633.

[42] Gao, W., \& Wang, J. (2014). Synthetic micro/nanomotors in drug delivery. Nanoscale, 6(18), 10486-10494.

[43] Shao, J., Kraft, J. C., Li, B., Yu, J., Freeling, J., Koehn, J., \& Ho, R. J. (2016). Nanodrug formulations to enhance HIV drug exposure in lymphoid tissues and cells: clinical significance and potential impact on treatment and eradication of HIV/AIDS. Nanomedicine, 11(5), 545564.

[44] Gupta, A., Bahal, R., Gupta, M., Glazer, P. M., \& Saltzman, W. M. (2016). Nanotechnology for delivery of peptide nucleic acids (PNAs). Journal of Controlled Release, 240, 302-311.

[45] Lee, J. H., \& Yeo, Y. (2015). Controlled drug release from pharmaceutical nanocarriers. Chemical engineering science, 125, 75-84.

[46] Lim, E. K., Chung, B. H., \& Chung, S. J. (2018). Recent advances in ph-sensitive polymeric nanoparticles for smart drug delivery in cancer therapy. Current drug targets, 19(4), 300-317.

[47] Ansari, S. A., Satar, R., Perveen, A., \& Ashraf, G. M. (2017). Current opinion in Alzheimer's disease therapy by nanotechnology-based

approaches. Current opinion in psychiatry, 30(2), 128-135.

[48] Kulkarni, A. D., Vanjari, Y. H., Sancheti, K. H., Belgamwar, V. S., Surana, S. J., \&Pardeshi, C. V. (2015). Nanotechnology-mediated nose to brain drug delivery for Parkinson's disease: a mini review. Journal of drug targeting, 23(9), 775-788.

[49] Nasiruddin, M., Neyaz, M., \& Das, S. (2017). Nanotechnology-Based approach in tuberculosis treatment. Tuberculosis research and treatment,2017, 1-12.DOI :https://doi.org/10.1155/2017/4920209.

[50] Bose, R. J., Lee, S. H., \& Park, H. (2016). Biofunctionalized nanoparticles: an emerging drug delivery platform for 
various disease treatments. Drug discovery today, 21(8), 1303-1312.

[51] Jiang, D., England, C. G., \& Cai, W. (2016). DNA nanomaterials for preclinical imaging and drug delivery. Journal of Controlled Release, 239, 27-38.

[52] Gao, Y., Xie, J., Chen, H., Gu, S., Zhao, R., Shao, J., \& Jia, L. (2014). Nanotechnology-based intelligent drug design for cancer metastasis treatment. Biotechnology

Advances, 32(4), 761-777.

[53] Kumar, L., Verma, S., Prasad, D. N., Bhardwaj, A., Vaidya, B., \& Jain, A. K. (2015). Nanotechnology: a magic bullet for HIV AIDS treatment. Artificial cells, nanomedicine, and biotechnology, 43(2), 71-86.

[54] Franci, G.; Falanga, A.; Galdiero, S.; Palomba, L.; Rai, M.; Morelli, G.; Galdiero, M. (2015). Silver Nanoparticles as Potential Antibacterial Agents. Molecules, 20, 8856-8874.

[55] Pi, F., Vieweger, M., Zhao, Z., Wang, S., \& Guo, P. (2016). Discovery of a new method for potent drug development using power function of stoichiometry of homomeric biocomplexes or biological nanomotors. Expert opinion on drug delivery, 13(1), 23-36.

[56] Jackman, J. A., Lee, J., \& Cho, N. J. (2016). Nanomedicine for infectious disease applications: innovation towards broad-spectrum treatment of viral infections. Small, 12(9), 1133-1139.

[57] Cao, S., \& Woodrow, K. A. (2018). Nanotechnology approaches to eradicating HIV reservoirs. European Journal of Pharmaceutics and Biopharmaceutics. (in press).

[58] Rai, M., Ingle, A. P., Gaikwad, S., Padovani, F. H., \& Alves, M. (2016). The role of nanotechnology in control of human diseases: perspectives in ocular surface diseases. Critical reviews in biotechnology, 36(5), 777-787.

[59] Karimi, M., Zare, H., Bakhshian Nik, A., Yazdani, N., Hamrang, M., Mohamed, E.,
... \& Hamblin, M. R. (2016). Nanotechnology in diagnosis and treatment of coronary artery disease. Nanomedicine, 11(5), 513-530.

[60] Choudhary, S., \& Devi, V. K. (2015). Potential of nanotechnology as a delivery platform against tuberculosis: current research review. Journal of Controlled Release, 202, 65-75.

[61] Ma, J., Porter, A. L., Aminabhavi, T. M., \& Zhu, D. (2015). Nano-enabled drug delivery systems for brain cancer and Alzheimer's disease: research patterns and opportunities. Nanomedicine: Nanotechnology, Biology and Medicine, 11(7), 1763-1771. 